\title{
Role of neuronal and inducible nitric oxide synthases in the guinea pig ileum myenteric plexus during in vitro ischemia and reperfusion
}

\author{
C. GIARONI, ${ }^{\star}$ S. MARCHET,${ }^{\star}$ E. CARPANESE,${ }^{\star}$ V. PRANDONI, ${ }^{\star}$ R. OLDRINI, ${ }^{\star}$ B. BARTOLINI, + E. MORO,$\dagger$ \\ D. VIGETTI, $\ddagger$ F. CREMA, $\dagger$ S. LECCHINI ${ }^{\star} \&$ G. FRIGO $\dagger$ \\ ${ }^{\star}$ Department of Clinical and Experimental Medicine, University of Insubria, Varese, Italy \\ $\dagger$ Department of Internal Medicine and Therapeutics, Section of Pharmacology, Pavia, Italy \\ \#Department of Surgical and Morphological Sciences, University of Insubria, Varese, Italy
}

\begin{abstract}
Background Intestinal ischemia and reperfusion (I/R) injury leads to abnormalities in motility, namely delay of transit, caused by damage to myenteric neurons. Alterations of the nitrergic transmission may occur in these conditions. This study investigated whether an in vitro $I / R$ injury may affect nitric oxide (NO) production from the myenteric plexus of the guinea pig ileum and which NO synthase (NOS) isoform is involved. Methods The distribution of the neuronal (n) and inducible (i) NOS was determined by immunohistochemistry during $60 \mathrm{~min}$ of glucose/ oxygen deprivation (in vitro ischemia) followed by 60 min of reperfusion. The protein and mRNA levels of nNOS and iNOS were investigated by Westernimmunoblotting and real time RT-PCR, respectively. NO levels were quantified as nitrite/nitrate. Key Results After in vitro $I / R$ the proportion of nNOSexpressing neurons and protein levels remained unchanged. nNOS mRNA levels increased $60 \mathrm{~min}$ after inducing ischemia and in the following 5 min of reperfusion. iNOS-immunoreactive neurons, protein and $m R N A$ levels were up-regulated during the whole $I / R$ period. A significant increase of nitrite/nitrate levels was observed in the first 5 min after inducing $I / R$ and was significantly reduced by $N^{\mathrm{\omega}}$-propyl-L-arginine and $1400 \mathrm{~W}$, selective inhibitors of nNOS and iNOS,
\end{abstract}

Address for Correspondence

Dr. Cristina Giaroni PhD, Department of Clinical and

Experimental Medicine, University of Insubria, via H. Dunant

5, I-21100 Varese, Italy.

Tel: +39 0332 217412; fax: +39 0332 217119;

e-mail: cristina.giaroni@uninsubria.it

Received: 30 July 2012

Accepted for publication: 15 November 2012 respectively. Conclusions e Inferences Our data demonstrate that both iNOS and nNOS represent sources for $N O$ overproduction in ileal myenteric plexus during $I / R$, although iNOS undergoes more consistent changes suggesting a more relevant role for this isoform in the alterations occurring in myenteric neurons following $I / R$.

Keywords guinea pig ileum, in vitro ischemial reperfusion, myenteric plexus, nitric oxide, nitric oxide synthase.

\section{INTRODUCTION}

Intestinal ischemia/reperfusion (I/R) injury represents an important clinical problem which may occur as a consequence of embolism, arterial or venous thrombosis, shock, ${ }^{1}$ intestinal transplantation, necrotising enterocolitis in the human premature newborn or chronic inflammatory diseases. ${ }^{2-4} \mathrm{I} / \mathrm{R}$ injury causes severe damage particularly to the mucosal and muscle layers and neurons. ${ }^{5-7}$ The functional consequences of this scenario include impairment of nutrient absorption, altered intestinal barrier function against bacterial translocation and disturbed motility. ${ }^{5,6,8}$ Adaptive changes of enteric neuronal circuitries modulating the intestinal motor function have been documented after both in vivo and in vitro I/R conditions. ${ }^{9-11}$ Among the major enteric neurotransmitter pathways, the nitrergic transmission has been suggested to participate in the motor disturbances caused by an $\mathrm{I} / \mathrm{R}$ injury to the gut. In physiologic conditions, nitric oxide $(\mathrm{NO})$ plays a pivotal role in the inhibitory regulation of peristalsis. ${ }^{12,13} \mathrm{NO}$ is synthesized by the neuronal (n), endothelial (e) and inducible (i) isoforms of nitric oxide synthase (NOS), all of which have been localized in 
myenteric neurons of different species. ${ }^{14-17}$ nNOS is constitutively expressed in myenteric neurons ${ }^{15-17}$ and is the predominant source for the generation of NO mediating non-adrenergic non-cholinergic inhibition of smooth muscle contraction. ${ }^{18}$ In myenteric neurons, expression of iNOS, but not of nNOS or eNOS, is enhanced during disease states, such as intestinal inflammation ${ }^{19,20}$ and diabetes. ${ }^{21}$ In these conditions, large amounts of NO may cause damage to different cell types, including neurons, by the formation of peroxynitrite and nitrotyrosine. ${ }^{20,22}$ Previous studies suggest that the activity of the diverse NOS isoforms may be differentially regulated during intestinal $I / R$, depending on the different experimental model and on the degree of damage. In the rat ileum, after a severe in vivo I/R injury, iNOS up-regulation was correlated with a decrease of the intestinal transit. ${ }^{23}$ Conversely, in the same animal model, a mild I/R injury induced a reduction of nNOS activity, which was correlated with a transitory impairment of the non-adrenergic noncholinergic inhibitory response. ${ }^{24}$ Such changes of the intestinal motor function may rely upon alterations of NOS containing myenteric neurons. In the rat ileum, a significant increase in the number of myenteric neurons expressing NOS immunoreactivity has been demonstrated after an in vivo I/R injury. ${ }^{25}$ Administration of $N \epsilon$-nitro-L-arginine methyl ester, a nonselective NOS inhibitor, prevented the increase of NOS immunoreactivity induced by $I / R$, suggesting the occurrence of a positive feedback between NO production and NOS expression. In the guinea pig ileum, mild in vivo I/R damage induced swelling and distortion of dendrites of NOS-expressing descending inhibitory motor neurons. ${ }^{26}$

In the present study, to further investigate the involvement of the nitrergic transmission during $I / R$, we evaluated whether an in vitro $\mathrm{I} / \mathrm{R}$ injury may acutely affect NO production from the guinea pig ileum muscle wall. In addition, the hypothesis that nNOS and iNOS isoforms may represent sources for NO in these experimental conditions was investigated. The potential different roles of the two isoforms was evaluated using molecular biology, morphological and functional approaches.

\section{MATERIALS AND METHODS}

\section{Animals and tissue preparation}

Male Dunkin-Hartley guinea pigs (Harlan Italy, Correzzana, Monza, Italy), weighing between 300 and $350 \mathrm{~g}$, were housed in groups of four under controlled environmental conditions (temperature $22 \pm 2{ }^{\circ} \mathrm{C}$; relative humidity $60-70 \%$ ) with free access to a standard diet and water, and were maintained at a regular 12/12-h light/dark cycle. Principles of good laboratory animal care were followed and animal experimentation was in compliance with specific national and international laws and regulations. Animals were sacrificed by decapitation and $8 \mathrm{~cm}$ segments of the ileum, approximately $5 \mathrm{~cm}$ oral to the ileocaecal junction, were rapidly excised and rinsed with a physiological ice-cold Tyrode's solution [composition $\left(\mathrm{mmol} \mathrm{L}^{-1}\right): 137$ $\mathrm{NaCl} ; 2.68 \mathrm{KCl} ; 1.8 \mathrm{CaCl}_{2} .2 \mathrm{H}_{2} \mathrm{O} ; 2 \mathrm{MgCl}_{2} ; 0.47 \mathrm{NaH}_{2} \mathrm{PO}_{4} ; 11.9$ $\mathrm{NaHCO}_{3} ; 5.6$ glucose]. Whole wall intestinal segments were fixed and stored for successive immunohistochemistry experiments, as described below. Overflow experiments were carried out on mucosa-deprived ileal segments. Western immunoblot and real time RT-PCR studies were conducted using preparations consisting of external longitudinal muscle layer segments with attached myenteric plexus (LMMP) obtained immediately after excision of ileal segments.

In vitro ischemic conditions were reproduced by suspending intestinal preparations in $3 \mathrm{~mL}$ organ baths superfused with an oxygen and glucose deprived Tyrode's solution. Oxygen deprivation was obtained by bubbling the perfusing medium with a mixture of $\mathrm{N}_{2}-\mathrm{CO}_{2}(95-5 \%)$. The effect of reperfusion was evaluated by substituting the hypoxic/hypoglycaemic medium with a normal oxygenated glucose-containing Tyrode's solution. During overflow studies, ileal segments were exposed to in vitro ischemic conditions for $60 \mathrm{~min}$ and subsequently reperfused for another $60 \mathrm{~min}$ period. For immunohistochemistry, Western immunoblot, real time RT-PCR studies, intestinal specimens after being perfused with an oxygenated Tyrode's solution maintained at $36.5^{\circ} \mathrm{C}$ for a $60 \mathrm{~min}$ equilibration period, were exposed to in vitro ischemic conditions for 5, 30 or $60 \mathrm{~min}$ and then reperfused for 5, 30 and $60 \mathrm{~min}$. This time course for glucose/oxygen deprivation was chosen given that enteric neurons are not irreversibly damaged after $60 \mathrm{~min}$ ischemia. ${ }^{8}$ Control experiments of Western immunoblotting and real time RT-PCR were carried out by exposing intestinal specimens to a normal glucose-containing and oxygenated medium for 5, 30, 60, 65,90 , and $120 \mathrm{~min}$ after the equilibration period. Tissue samples were either stored at $-70^{\circ} \mathrm{C}$ for successive Western immunoblotting assay or stored in a preserving solution for downstream real time RT-PCR (RNA later ${ }^{\mathrm{TM}}$; Ambion Life Technologies Italia, Monza, Italy).

\section{Immunohistochemistry}

Segments of the guinea pig ileum were fixed for $4 \mathrm{~h}$ at room temperature (RT) in $0.2 \mathrm{~mol} \mathrm{~L}^{-1}$ sodium phosphate-buffer (PBS: $0.14 \mathrm{~mol} \mathrm{~L}^{-1} \mathrm{NaCl}, 0.003 \mathrm{~mol} \mathrm{~L}^{-1} \mathrm{KCl}, 0.015 \mathrm{~mol} \mathrm{~L}^{-1} \mathrm{Na}_{2} \mathrm{HPO}_{4}$ $\left.0.0015 \mathrm{~mol} \mathrm{~L}^{-1} \mathrm{KH}_{2} \mathrm{PO}_{4}\right) \mathrm{pH} 7.4,4 \%$ formaldehyde and $0.2 \%$ picric acid. Preparations were then cleared of fixative and stored at $4{ }^{\circ} \mathrm{C}$ in PBS containing $0.05 \%$ thimerosal. LMMP wholemount ileal preparations were then prepared according to the method of ${ }^{27}$ Briefly, after blocking aspecific sites with PBS, $1 \%$ Triton X-100 and 10\% normal horse serum (NHS) (Euroclone, Celbio, Milan, Italy) for $1 \mathrm{~h}$, preparations were incubated with optimally diluted primary antibodies (Table 1). Double labelling was performed during consecutive incubation times: firstly, the primary antibody raised against either iNOS or nNOS was added overnight at $4{ }^{\circ} \mathrm{C}$, then incubation with secondary antibodies followed for $2 \mathrm{~h}$ at RT. Whole mounts were successively incubated overnight at $4{ }^{\circ} \mathrm{C}$ with a biotinylated antibody to $\mathrm{HuC} / \mathrm{D}$ (neuronal cell marker) or with an antibody to S100 (glial cell marker) (Table 1). Incubation for $2 \mathrm{~h}$ with either streptavidin conjugated $\mathrm{Cy} 3$ or with an appropriate secondary antibody was then performed at RT. Double labelling with iNOS and nNOS was performed following the same procedures, by adding the two primary antibodies consecutively. Preparations were mounted 
Table 1 Primary and secondary antisera and their respective dilutions used for western blot (WB) assay and immunohistochemistry (HC)

\begin{tabular}{|c|c|c|c|c|}
\hline Antiserum & Dilution (WB) & Dilution $(\mathrm{HC})$ & Source & Host species \\
\hline \multicolumn{5}{|l|}{ Primary antisera } \\
\hline iNOS & $1: 200$ & $1: 250$ & Santa Cruz (sc8310; H-174) & Rabbit \\
\hline iNOS & - & $1: 50$ & AbCam (ab49999) & Mouse \\
\hline nNOS & $1: 500$ & $1: 250$ & Millipore (AB1529) & Sheep \\
\hline HUC/D & - & $1: 100$ & Molecular Probes, Invitrogen (A-21272) & Mouse \\
\hline S-100 & & $1: 1000$ & Dako (Z0311) & Rabbit \\
\hline$\alpha$-tubulin & $1: 1000$ & - & Sigma-Aldrich (T-6199 DM-1A) & Mouse \\
\hline \multicolumn{5}{|l|}{ Secondary antisera \& streptavidin complexes } \\
\hline Anti-sheep FITC & & $1: 150$ & Millipore (AP147F) & Rabbit \\
\hline Anti-rabbit Alexa Fluor 488 & & $1: 200$ & Molecular Probes (A21206) & Donkey \\
\hline Anti-mouse Alexa Fluor 488 & & $1: 300$ & Molecular Probes (A21202) & Donkey \\
\hline Cy3-conjugated streptavidin & & $1: 500$ & Amersham (PA43001) & \\
\hline Anti-sheep IgG horseradish peroxidase-conjugated & & $1: 20000$ & Millipore (AP147P) & Rabbit \\
\hline Anti-rabbit IgG horseradish peroxidase-conjugated & $1: 10000$ & & Amersham (NA934) & Donkey \\
\hline Anti-mouse IgG horseradish peroxidase-conjugated & $1: 10000$ & & Millipore (AP126P) & Millipore (AP147F) \\
\hline
\end{tabular}

Supply companies: Amersham, GE Healthcare, Buckinghamshire, UK; Abcam, Cambridge, UK; Millipore Co, Billerica, MA, USA; Dako, DK-2600 Glostrup, Demark; Molecular Probes, Invitrogen, Carlsbad, CA, USA; Santa Cruz Biotechnology, Inc, CA,USA; Sigma-Aldrich, Milano, Italy.

onto glass slides, using a mounting medium with DAPI (Vectashield $^{\circledR}$; Vector Lab, Burlingame, CA, USA). Neuron counts were made on HuC/D stained LMMPs, obtained from at least four animals, digitized by capturing as many as 40X objective microscope fields $\left(0.287 \mathrm{~mm}^{2}\right)$ as possible (10-15 fields). The total value was divided by the total image field area considered and expressed as the number of cell bodies $\mathrm{mm}^{-2}$. To establish the proportion of iNOS and nNOS expressing myenteric neurons, quantitative analysis of double fluorescently labelled ileal whole mounts was performed as previously described. ${ }^{27,28}$ Negative controls and interference control staining was evaluated by omitting one or both of the primary antibodies, or one of the secondary antibodies. Preparations were analyzed by confocal microscopy on a Leica TCS SP5 confocal laser scanning system (Leica Microsystems $\mathrm{GmbH}$, Wetzlar, Germany) and pictures were processed using Adobe-Photoshop CS2.0 software.

\section{Western immunoblot analysis of iNOS and nNOS}

iNOS and nNOS protein level analysis was carried out starting from LMMPs preparations with successive centrifugations according to the method described ${ }^{27}$ The purified membrane fraction and the supernatant were boiled for 2 min after dilution with Laemmli sample buffer ${ }^{29}$ and processed as described elsewhere. ${ }^{27} \mathrm{Mem}-$ branes were incubated with optimally diluted primary and horseradish peroxidase-conjugated secondary antisera (Table 1). Blots for iNOS and nNOS were developed using an enhanced chemiluminescence technique (ECL advance Amersham Pharmacia Biotech, Cologno Monzese, Italy). Signal intensity was quantified by densitometric analysis using the NIH image software 1.61 (downloadable at http://rsb.info.nih.gov/nih-image). In each membrane $\alpha$-tubulin was monitored and used as protein loading control. Experiments were performed at least four times for each different preparation. The effect of either in vitro $\mathrm{I} / \mathrm{R}$ or of superfusion with a normal glucose-containing oxygenated medium on protein levels was expressed as the percentage variation $v S$ values obtained in preparations exposed to normal metabolic conditions and collected at the end of the equilibration period. Specificity of iNOS and nNOS primary antibodies was evaluated by testing their selectivity in RAW 264.7 macrophage cells and in the rat hippocampus (data not shown), respectively, and by omission of the primary antibody.

\section{Real time quantitative RT-PCR}

Total RNA was extracted from LMMPs preparations with TRIzol (Invitrogen) and treated with DNase I (DNase Free, Ambion) to remove any traces of contaminating DNA. cDNA was obtained retrotranscribing $2 \mu \mathrm{g}$ of total RNA using the High Capacity cDNA synthesis kit (Applied Biosystems, Life Technologies, Grand Island, NY, USA). Quantitative RT-PCR was performed on the Abi Prism 7000 real-time thermocyclator (Applied Biosystems) with Power Sybr Green Universal PCR Master Mix (Applied Biosystems) following manufacturer's instructions. Primers were designed using Primer Express software (Applied Biosystems) on the basis of available sequences deposited in public database. Primer sequences were: n-NOS, 5'-ACGGAGCGTGGCTACAGTTT-3'; 5'-TCCTT GATGTCACGCACAATTT-3'; iNOS: 5'-GCAGCAGCGGCTTC ACA-3'; $5^{\prime}$-ACATCCAAACAGGAGCGTCAT- ${ }^{\prime}$; $\beta$-actin $5^{\prime}$-ACGG AGCGTGGCTACAGTTT-3', 5'-TCCTTGATGTCACGCACAAT TT-3'; GAPDH， 5'-CGGATTTGGCCGTATTGG-3', 5'-AATATC CACTTTGCCAGACATGAA-3'. For quantitative RT-PCR a final concentration of $100 \mathrm{nmol} \mathrm{L}^{-1}$ for each primer was used. Primers were designed to have a similar amplicon size and similar amplification efficiency as required for the utilization of the $\Delta \Delta \mathrm{Ct}$ method to compare gene expression. ${ }^{30} \beta$-actin and GADPH were used as housekeeping genes. Experiments were performed at least four times for each different preparation. The effect of either in vitro $\mathrm{I} / \mathrm{R}$ or of superfusion with a normal glucose-containing oxygenated medium on mRNA levels was expressed as the percentage variation vs values obtained in preparations exposed to normal metabolic conditions.

\section{Overflow study}

NO overflow was accomplished using mucosa-deprived ileal specimens. The submucosal layer was not routinely removed from the intestinal wall since preliminary experiments demonstrated that the release of NO oxidation products from the submucosal plexus was undetectable by our method of analysis. Silk ligatures were applied to each end of 1-2 cm long strips; one end was attached to a rigid support and the other to an isotonic transducer (load $1 \mathrm{~g}$ ) in $3 \mathrm{~mL}$ organ baths perfused at a constant rate of $1 \mathrm{~mL}$ min $^{-1}$ with Tyrode's gassed with $\mathrm{O}_{2}-\mathrm{CO}_{2}(95-5 \%)$ and maintained at $36.5^{\circ} \mathrm{C}$. After a $60 \mathrm{~min}$ equilibration period, three samples were 
collected over a period of 5 min for each sample and considered as controls, subsequently in vitro I/R conditions were applied, as described above. Test drugs were added to the superfusion medium after collection of the third control sample until the end of the experiment. Equilibration periods of $20 \mathrm{~min}$ were allowed after addition of $N^{\omega}$-propyl-L-arginine $\left(1 \mu \mathrm{mol} \mathrm{L}^{-1}\right)$ and $1400 \mathrm{~W}$ $\left(10 \mu \mathrm{mol} \mathrm{L}{ }^{-1}\right)$, selective inhibitors of nNOS and iNOS, respectively. A single drug concentration was tested on each intestinal preparation. After the equilibration period with the appropriate test drug, three samples were collected each over a period of $5 \mathrm{~min}$, before inducing in vitro I/R. At the end of the experiment, ileal samples were blotted and weighed $(189.73 \pm 5.34 \mathrm{mg}$; $n=33)$.

Samples were assayed for NO by means of the nitrite method based on the Griess reaction. ${ }^{31}$ Briefly, samples were incubated with Griess reagent $(0.5 \%$ sulfanilic acid, $0.15 \%$ 2-naphthylamine in $30 \%$ acetic acid) in a glycine- $\mathrm{NaOH}$ buffer. Nitrite $\left(\mathrm{NO}_{2}^{-}\right)$concentration in the samples was estimated by measuring the absorbance of the red-violet diazo dye at $548 \mathrm{~nm}$. $\mathrm{NO}_{3}{ }^{-}$concentration in each sample was calculated by subtracting $\mathrm{NO}_{2}{ }^{-}$concentration value to the total $\mathrm{NO}_{2}{ }^{-}$concentration, obtained by reducing nitrate $\left(\mathrm{NO}_{3}{ }^{-}\right)$ content in the sample to $\mathrm{NO}_{2}{ }^{-}$with cadmium. All reactions were conducted in triplicate. Standard $\mathrm{NO}_{2}{ }^{-}$and $\mathrm{NO}_{3}{ }^{-}$curves were constructed daily using $\mathrm{NaNO}_{2}$ and $\mathrm{NaNO}_{3}$ as standard.

To calculate the absolute amount of $\mathrm{NO}_{2}{ }^{-}$and $\mathrm{NO}_{3}{ }^{-}$, the concentration in each sample was normalized by the weight of each tissue preparation and collection duration and expressed as $\mu \mathrm{mol} \mathrm{g}$ tissue $^{-1} \mathrm{~min}^{-1}$. In normal metabolic conditions, the effect of test drugs on $\mathrm{NO}_{2}{ }^{-}$and $\mathrm{NO}_{3}{ }^{-}$overflow was expressed as percentage variation with respect to control values. Changes of $\mathrm{NO}_{2}{ }^{-}$and $\mathrm{NO}_{3}{ }^{-}$overflow induced by different treatments during in vitro $\mathrm{I} / \mathrm{R}$, were expressed as percentage variation with respect to values of spontaneous overflow obtained for each treatment in normal metabolic conditions.

\section{Statistical analysis}

For statistical analysis the GraphPad Instat statistical package (version 5.03; GraphPad software, San Diego, CA, USA) was used. Data were analyzed either by one sample $t$-test, Student's $t$-test or analysis of variance (ANOVA) followed by an appropriate post hoc comparison tests (Dunnett's or Tukey's Multiple Comparisons tests) or two way ANOVA, as indicated either in the text or in the legends. Differences were considered statistically significant when $P$ values $\leq 0.05$

\section{Drugs and materials}

$N^{5}$-[Imino(propylamino/methyl]-L-ornithine hydrochloride $\left(N^{\omega}\right.$ propyl-L-arginine hydrochloride) and 3-aminomethylbenzylacetamidine dihydrochloride (1400 W) were purchased from Tocris (Bristol, UK). All other reagents were purchased either from Sigma-Aldrich or from BioRad (Segrate, MI, Italy).

\section{RESULTS}

\section{Distribution of nNOS-IR and iNOS-IR in LMMP whole-mounts preparations of the guinea pig ileum in normal metabolic conditions and after in vitro $I / R$}

The number of myenteric neurons, as indicated by $\mathrm{HuC} / \mathrm{D}$ cytoplasmic staining, remained unchanged during ischemia/reperfusion with respect to control preparations (Fig. 1A). After in vitro I/R a proportion of myenteric neurons displayed $\mathrm{HuC} / \mathrm{D}$-IR traslocation from the cytoplasm to the nucleus (data not shown). In both normal metabolic conditions and after $I / R$, nNOS-IR was observed in the cytoplasm of myenteric neurons. Some neuronal cells had a large cell body with club-like dendrites, while others were small with an ovoidal shape and with no visible dendrites. nNOS-IR was evidenced also in neuronal fibers within the ganglia and along the interconnecting strands, and in the secondary and tertiary fiber tracts. (Fig. 2A,C). In normal metabolic conditions the percentage of myenteric neurons staining for nNOS was $23.50 \pm 1.94 \%$, $n=4$. There was no significant change in the percentage of nNOS immunopositive myenteric neurons at different times after in vitro $\mathrm{I} / \mathrm{R}$ with respect to the value obtained in control preparations (Fig. 1B; Fig. 2D,F, G,I). In both control and I/R preparations, iNOS staining was observed in the soma of myenteric neurons with an ovoidal shape and no visible dendrites (Fig. 3A,C). In normal metabolic conditions the percentage of iNOS immunopositive neurons was $5.75 \pm 0.75 \%, n=4$. The proportion of iNOS immunopositive neurons significantly increased $60 \mathrm{~min}$ after ischemia and during the whole reperfusion period, with respect to the value obtained in controls (Fig. 1C, Fig. 3D,F, G,I). In normal metabolic conditions the majority of iNOS positive neurons (97.33 $\pm 0.94 \%$, $n=4)$ expressed nNOS-IR (Fig. 4A-C). All iNOS-IR neurons appearing during $\mathrm{I} / \mathrm{R}$ conditions were also nNOS immunopositive (Fig. 4D-I). Double labelling with S100 did not reveal the presence of nNOS-IR and iNOS-IR in myenteric glial cells, both in normal metabolic conditions and after I/R (data not shown).

\section{Levels of expression of nNOS and iNOS in the guinea pig ileum LMMP preparations after in vitro $I / R$}

Western blot analysis of nNOS in the guinea pig ileum LMMP preparations (Fig. 5A,B) and in the rat hippocampus (data not shown) revealed one band at $155 \mathrm{kDa}$. nNOS protein levels in the membrane and soluble fraction of LMMP preparations subjected to I/R conditions remained unchanged with respect to the relative controls (Fig. 5A).

Western blot analysis of iNOS in the guinea pig ileum LMMP preparations (Fig. 5C,D) and in RAW 264.7 macrophage cells (data not shown) revealed one band at $125 \mathrm{kDa}$. After I/R, iNOS levels significantly increased both in the membrane and soluble fraction of LMMPs, with respect to the relative controls (Fig. 5C). 


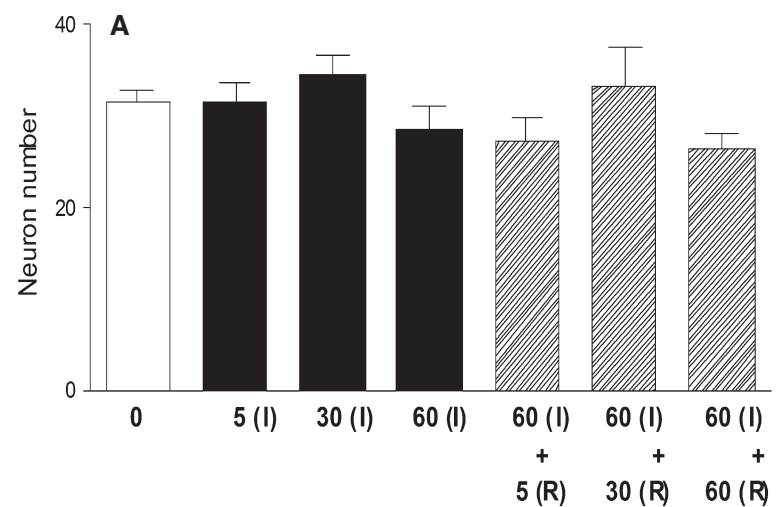

Time $(\min )$

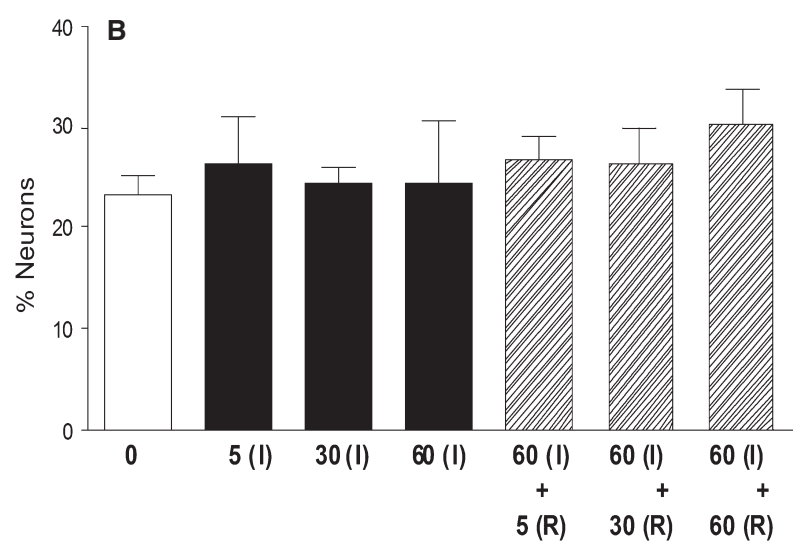

Time $(\min )$

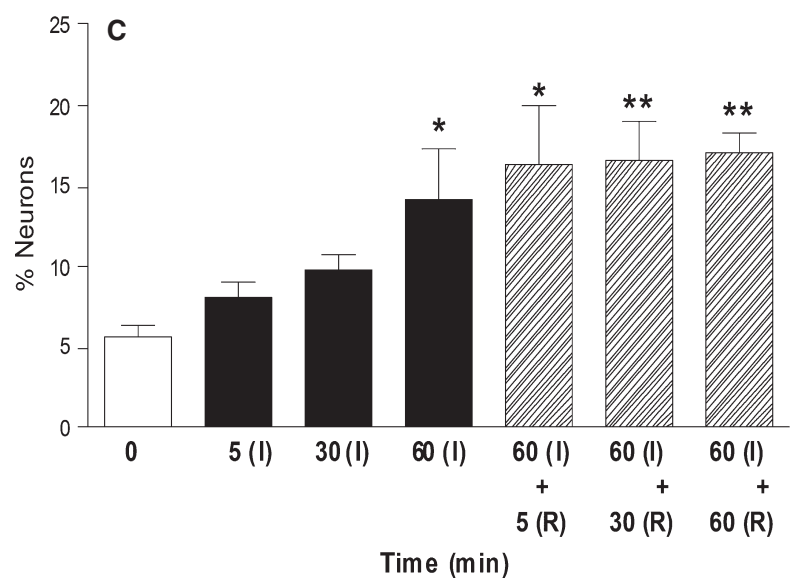

Figure 1 (A) Number of myenteric neurons $\mathrm{mm}^{-2}$ staining for $\mathrm{HuC} / \mathrm{D}$ in guinea pig ileum whole-mounts preparations in control preparations (empty bar), at different times after inducing in vitro ischemia (full bar) and after reperfusion ( $\mathrm{R}$, slash). Percentage of myenteric neurons staining for HuC/D and immunopositive for either nNOS (B) or iNOS $(\mathrm{C})$ in guinea pig ileum whole-mounts preparations in control preparations (empty bar), at different times after inducing in vitro ischemia (full bar) and after reperfusion ( $\mathrm{R}$, slash). Values are expressed as mean \pm SEM of at least four experiments. Vertical bars indicate SEM ${ }^{\star} P<0.05,{ }^{\star}{ }^{\star} P<0.01$ by one way ANOva followed by Dunnett's test.
nNOS and iNOS protein levels obtained from LMMP preparations superfused with a normal and oxygenated Tyrode's solution for 5, 30, 60, 65, 90 and 120 min after the equilibration period were not significantly different from the amount obtained in control preparations collected at the end of the equilibration period (Fig. 5B,D).

Levels of nNOS and iNOS mRNA in the guinea pig ileum LMMP preparations after in vitro $I / R$

Quantitative RT-PCR analysis of nNOS and iNOS mRNA in guinea pig ileum LMMP preparations is shown in Fig. 6. Both in control and in I/R preparations analyses of gene expression with respect to $\beta$-actin and GAPDH, were not significantly different (data not shown), thus, for the sake of simplification, only $\beta$-actin normalized values are reported in Fig. 6.

nNOS mRNA levels significantly increased with respect to the relative controls $60 \mathrm{~min}$ after inducing in vitro ischemia and after $5 \mathrm{~min}$ of reperfusion (Fig. 6A).

iNOS gene expression levels (Fig. 6C) significantly increased $5 \mathrm{~min}$ after inducing ischemia and remained elevated throughout the ischemic period. Enhancement of iNOS mRNA levels was also observed during reperfusion (Fig. 6C).

In LMMP preparations superfused with a normal and oxygenated Tyrode's solution for 5, 30, 60, 65, 90 and $120 \mathrm{~min}$ after the equilibration period, nNOS and iNOS mRNA levels remained unchanged with respect to control preparations (Fig. 6B,D).

In LMMP control preparations, iNOS levels were about 17-fold lower compared to nNOS levels (data not shown).

\section{Effect of in vitro $\mathrm{I} / \mathrm{R}$ on $\mathrm{NO}_{2}{ }^{-}$and $\mathrm{NO}_{3}{ }^{-}$ production from the guinea pig ileum}

After the 60 min equilibration period, $\mathrm{NO}_{2}{ }^{-}$and $\mathrm{NO}_{3}{ }^{-}$ concentrations in the superfusate from isolated mucosa-deprived segments of the guinea pig ileum were $4.02 \pm 0.004 \mu \mathrm{mol} \mathrm{g}{ }^{-1} \min ^{-1}(n=4)$ and $11.00 \pm 2.36$ $\mu \mathrm{mol} \mathrm{g}{ }^{-1} \min ^{-1}(n=4)$, respectively, and were stable over at least $150 \mathrm{~min}$ (Fig. 7A,C).

Both $\mathrm{NO}_{2}{ }^{-}$and $\mathrm{NO}_{3}{ }^{-}$concentration significantly increased over control values during the first $5 \mathrm{~min}$ after inducing in vitro ischemia, and returned to values similar to those obtained in control conditions in the following collection periods under ischemic conditions. A significant enhancement of $\mathrm{NO}_{2}{ }^{-}$and $\mathrm{NO}_{3}{ }^{-}$production was observed 5 min after reperfusion. $\mathrm{NO}_{2}{ }^{-}$and $\mathrm{NO}_{3}{ }^{-}$overflow tended to reach values not 
Figure 2 Immunohistochemical co-localization of nNOS with the neuronal marker $\mathrm{HuC} / \mathrm{D}$ in whole-mount preparations of the guinea pig ileum obtained from control preparations $(\mathrm{A}, \mathrm{B}$ and merged image $\mathrm{C})$ 60 min after in vitro ischemia $(\mathrm{D}, \mathrm{E}$ and merged image $\mathrm{F}$ ) and at 60 min of reperfusion after $60 \mathrm{~min}$ in vitro ischemia $(\mathrm{G}, \mathrm{H}$ and merged image I). The neuronal marker $\mathrm{HuC} /$ D stained the somata of all myenteric neurons $(\mathrm{B}, \mathrm{E}, \mathrm{H})$. Bar $50 \mu \mathrm{m}$.

Figure 3 Immunohistochemical co-localization of iNOS with the neuronal marker $\mathrm{HuC} / \mathrm{D}$ in whole-mount preparations of the guinea pig ileum obtained from control preparations $(\mathrm{A}, \mathrm{B}$ and merged image $\mathrm{C})$, $60 \mathrm{~min}$ after in vitro ischemia $(\mathrm{D}, \mathrm{E}$ and merged image $\mathrm{F}$ ) and at $60 \mathrm{~min}$ of reperfusion after $60 \mathrm{~min}$ in vitro ischemia $/ \mathrm{G}, \mathrm{H}$ and merged image I). The neuronal marker $\mathrm{HuC} /$ D stained the somata of all myenteric neurons (B,E,H). Bar $50 \mu \mathrm{m}$.
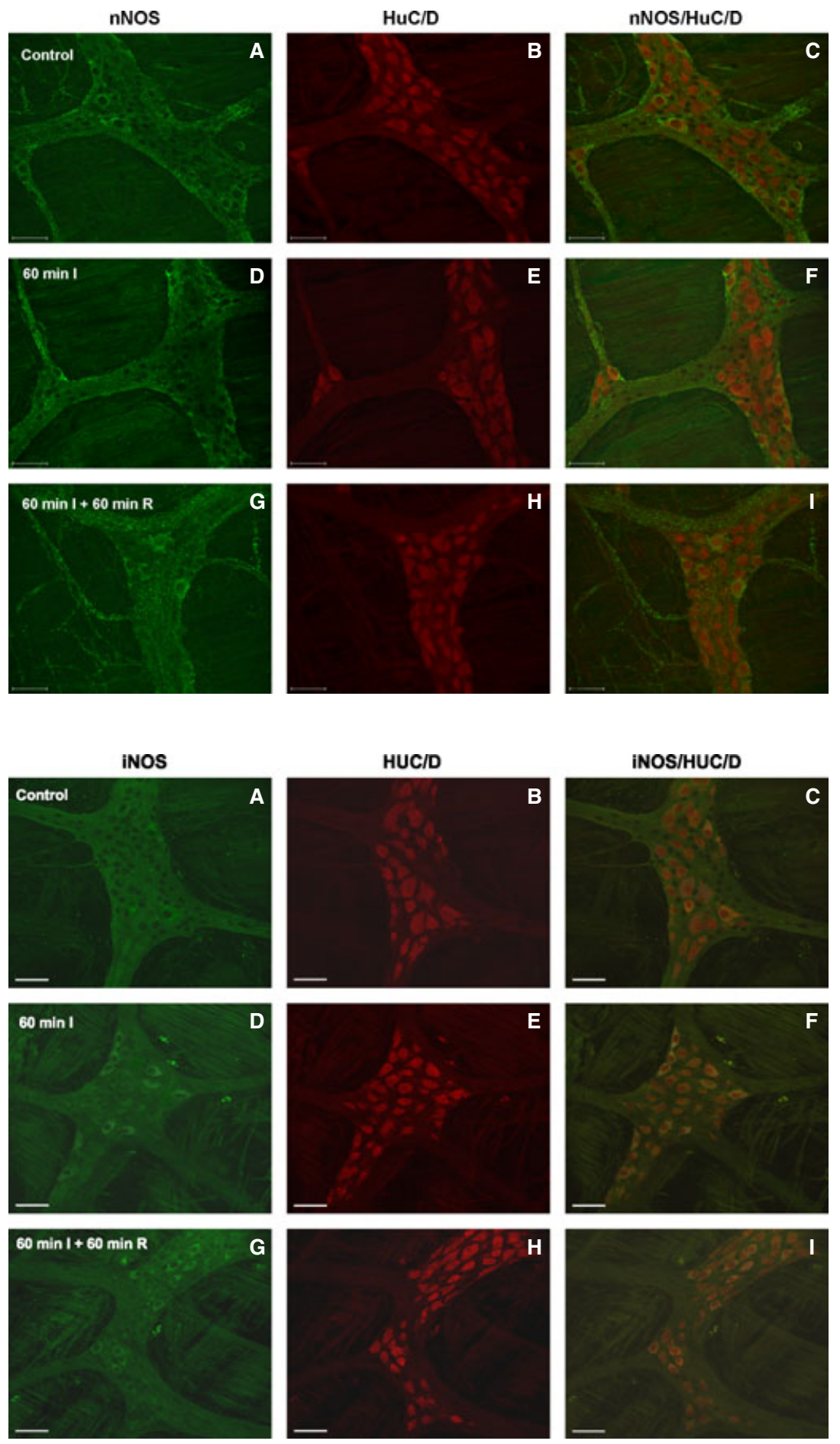

significantly different from controls 15 min after restoring normal metabolic conditions. The peak of $\mathrm{NO}_{2}{ }^{-}$and $\mathrm{NO}_{3}{ }^{-}$concentration observed at 5 min after reperfusion was significantly higher than the values obtained in the last $30 \mathrm{~min}$ of in vitro ischemia (Fig. 7B,D).
Effect of nNOS and iNOS blockade on in vitro I/R-induced on $\mathrm{NO}_{2}{ }^{-}$and $\mathrm{NO}_{3}{ }^{-}$production in the guinea pig ileum

$N^{\omega}$-propyl-L-arginine $\left(1 \mu \mathrm{mol} \mathrm{L}^{-1}\right)$ and $1400 \mathrm{~W}(10 \mu \mathrm{mol}$ $\mathrm{L}^{-1}$ ) significantly reduced the basal concentrations of 

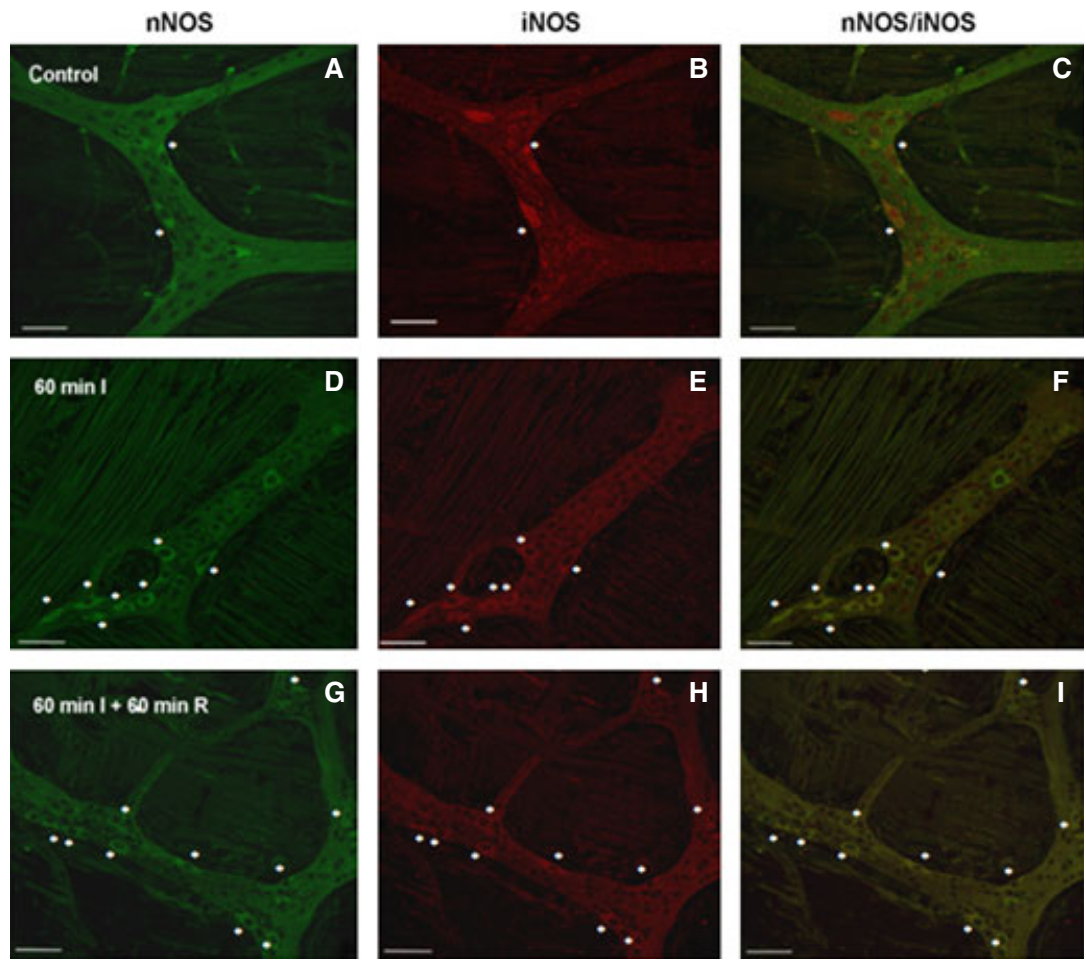

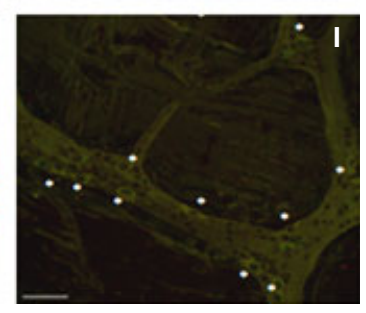

Figure 4 Confocal images showing co-localization of iNOS and nNOS in myenteric neurons of the guinea pig ileum obtained from control preparations $(\mathrm{A}, \mathrm{B}$ and merged image C), 60 min after in vitro ischemia (D,E and merged image F) and at $60 \mathrm{~min}$ of reperfusion after $60 \mathrm{~min}$ in vitro ischemia $(\mathrm{G}, \mathrm{H}$ and merged image I). Asterisks indicate myenteric neurons expressing both iNOS and nNOS. Bar $50 \mu \mathrm{m}$. both $\quad \mathrm{NO}_{2}{ }^{-} \quad(-13.00 \pm 3.91 \%, \quad n=7 \quad P<0.05$, $-23.83 \pm 5.21, n=6 P<0.01$, by one sample $t$-test, respectively) and $\mathrm{NO}_{3}{ }^{-}(-20.43 \pm 6.73, n=7 P<0.05$, $-30.50 \pm 6.91, n=6 P<0.01$, by one sample $t$-test, respectively) with respect to control values.

$N^{\omega}$-propyl-L-arginine and $1400 \mathrm{~W}$ significantly reduced $\mathrm{NO}_{2}{ }^{-}$and $\mathrm{NO}_{3}{ }^{-}$production during $\mathrm{I} / \mathrm{R}$. In these conditions, $1400 \mathrm{~W}$ reduced $\mathrm{NO}_{3}{ }^{-}$concentrations to a significantly greater extent than $N^{\omega}$-propyl-L-arginine (Fig. 8A,B).

\section{DISCUSSION}

An increasing body of evidence is available to suggest that an $\mathrm{I} / \mathrm{R}$ injury to the gut may induce severe damage to enteric neurons ${ }^{6,26}$ which may involve nitrergic enteric pathways. In the present study we have demonstrated that in the myenteric plexus of the guinea pig ileum, nNOS and iNOS, the predominant sources of NO from enteric neurons in physiological and pathological conditions, respectively, ${ }^{20,21}$ may participate to the increased NO production following an acute in vitro $\mathrm{I} / \mathrm{R}$ insult.

Our immunohistochemical findings show that in control preparations approximately $24 \%$ of myenteric neurons express nNOS, in agreement with the already reported percentage for nNOS expressing myenteric neurons in the guinea pig, mouse and rat ${ }^{21,26,32}$ small intestine. After in vitro I/R in ileal LMMPs, nNOS immunopositive myenteric neurons and protein levels did not change significantly with respect to values obtained under control conditions, while nNOS mRNA levels transiently increased 60 min after ischemia and $5 \mathrm{~min}$ after reperfusion. Changes in nNOS mRNA and protein expression have been demonstrated after in vivo and in vitro I/R injuries both at a central and peripheral level, suggesting that also the constitutive neuronal isoform may play a role during a metabolic insult. ${ }^{33,34}$ In human aortic smooth muscle cells, an nNOS promoter has been recently shown to contribute to rapidly up-regulate nNOS mRNA in response to hypoxia with a functionally significant effect on vascular smooth muscle contractility. ${ }^{35}$ In our model, nNOS mRNA, but not the protein, is transiently up-regulated. Delay of nNOS mRNA translation into the relevant protein was also demonstrated in the rat nodose ganglion and cerebellum after an hypoxic insult. ${ }^{33}$ Interestingly, in the myenteric plexus of the rat ileum, the number of nNOS positive cell bodies significantly increased $24 \mathrm{~h}$ after clamping the superior mesenteric artery. ${ }^{25}$

In the present study, immunohistochemical, Western immunoblot and RT-PCR data are provided to suggest that guinea pig ileum myenteric neurons constitutively express iNOS, as already documented by other studies carried out in the mouse, rat and 

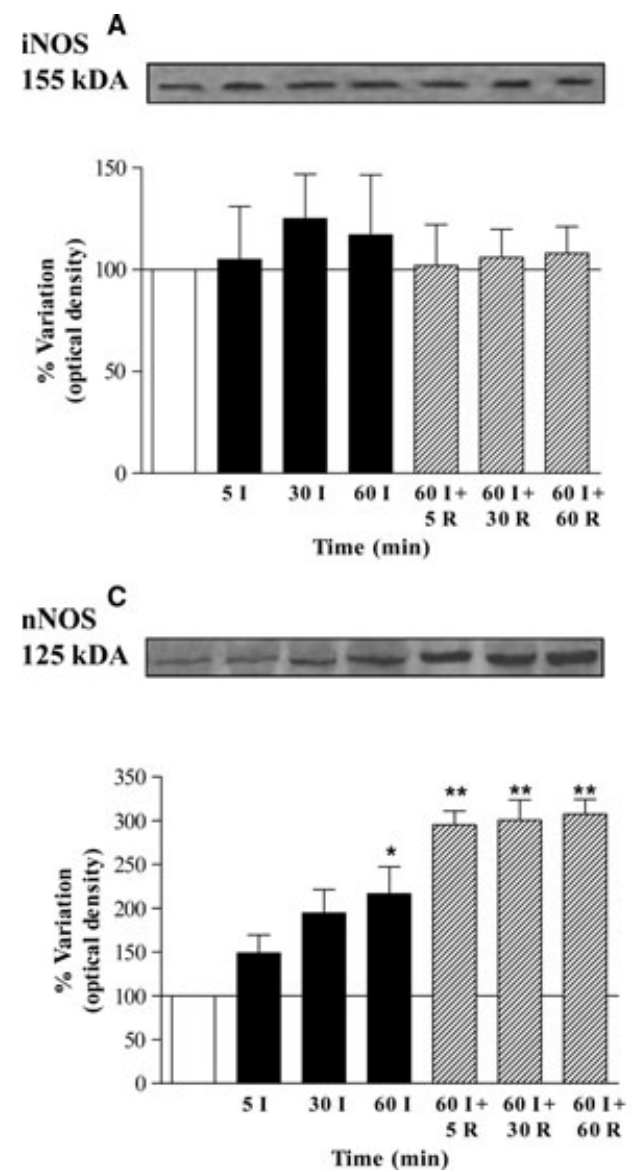
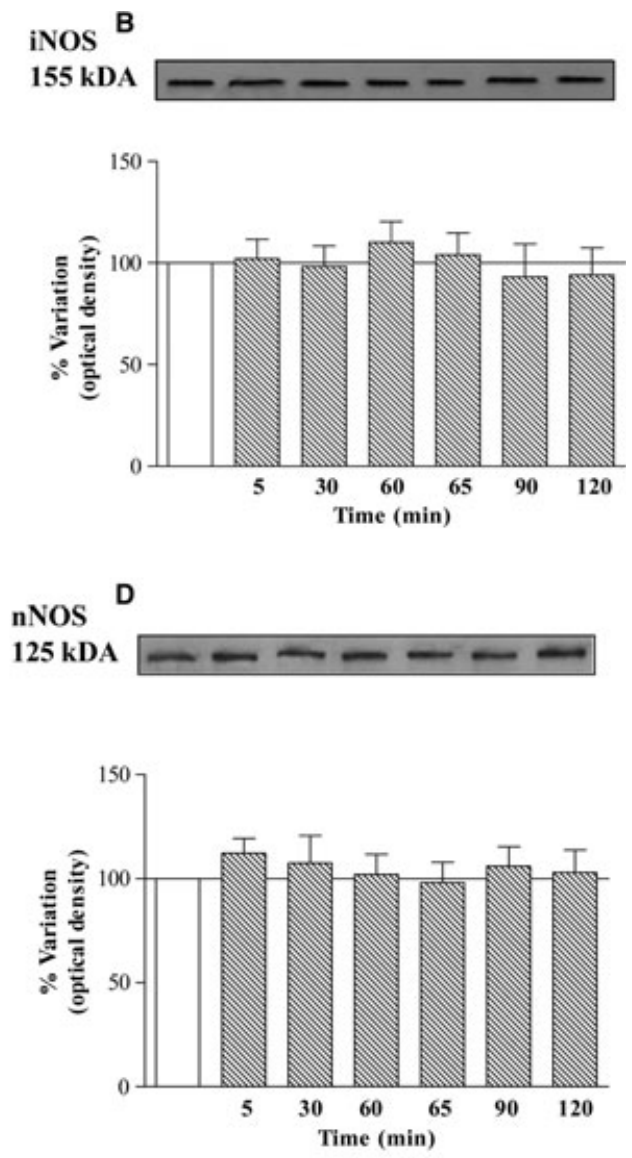

Figure 5 Levels of expression of nNOS and iNOS in the membrane (P, full bar) and in the supernatant (S, dotted bars) fractions obtained from guinea pig ileum LMMPs preparations at different times after inducing ischemia (I) and reperfusion (R) (A,C) and at different times after the equilibration period in normal metabolic conditions (B,D). Values are expressed as mean \pm SEM of at least four experiments of the percentage variation of optical density (OD) with respect to relative controls (empty bar). Vertical bars indicate SEM ${ }^{\star} P<0.05$, ${ }^{\star} P<0.01$ by one sample $t$-test. Blots representative of immunoreactive bands for nNOS and iNOS in the different experimental conditions are reported on top of each panel. Samples (100 $\mu \mathrm{g}$ ) were electrophoresed in SDS-10\% polyacrylamide gels. Numbers at the margins of the blots indicate relative molecular weights of the respective protein in $\mathrm{kDa}$.

guinea pig gut. ${ }^{14,17,36}$ The proportion of myenteric neurons expressing iNOS was smaller (about $6 \%$ of the total neuronal population) than the proportion of nNOS expressing neurons. This observation is in agreement with other studies reporting low iNOS immunoreactivity levels in the myenteric plexus of the guinea pig and rat gut. ${ }^{20,36,37}$ Accordingly, in control preparations iNOS mRNA levels were significantly lower with respect to those of nNOS. A consistent up-regulation of iNOS has been shown to occur in neuronal cells following I/R. ${ }^{38,39}$ Such an adaptive response could be found also in the guinea pig ileum where the percentage of iNOS-expressing myenteric neurons, protein and mRNA levels progressively increased from the first minutes after inducing in vitro ischemia and remained elevated during reperfusion. Our data indicate a major involvement of iNOS rather than nNOS in the changes occurring in myenteric neurons after I/R. In this regard, the observation that, iNOS-IR neurons, appearing after $\mathrm{I} / \mathrm{R}$, are $\mathrm{nNOS}$ positive may reflect a functional plasticity of myenteric neurons which activate different NOS isoforms depending on either physiological or pathological conditions. ${ }^{40}$ In particular, our observations strengthen the concept that in myenteric neurons, nNOS may represent the main source for NO involved in the physiological modulation of non-adrenergic non-cholinergic inhibitory motor responses of the gut. However, under pathological conditions, namely during I/R, within the same cell iNOS may replace nNOS in the synthesis of NO. As regards the molecular mechanisms underpinning upregulation of iNOS expression in our model, one of the most acceptable hypothesis involves hypoxia inducible factor-1 (HIF-1) which is described 

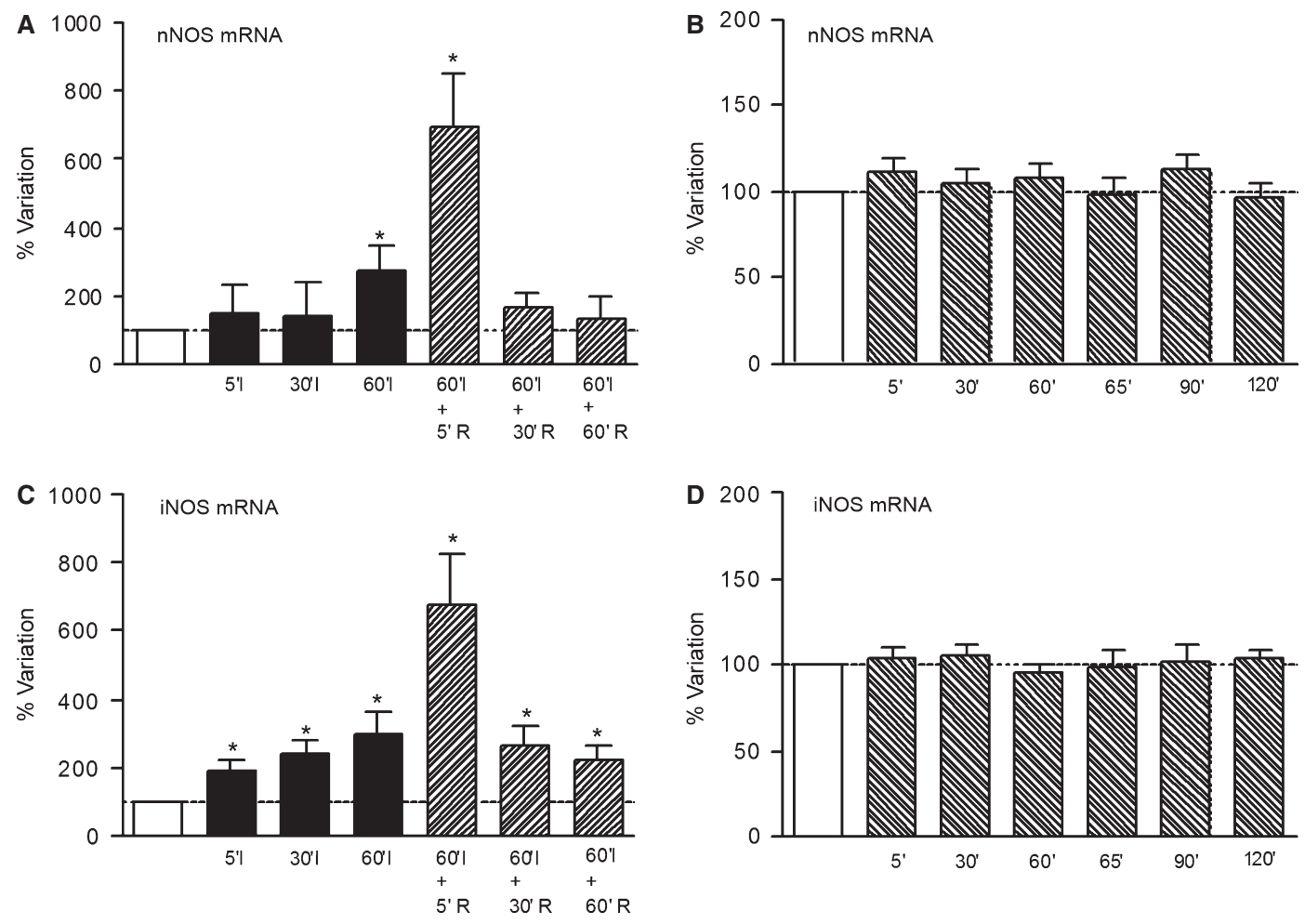

Figure 6 RT-PCR quantification of nNOS and iNOS transcripts in guinea pig ileum longitudinal muscle myenteric plexus preparations (LMMP) at different times after inducing in vitro ischemia (I, full bar), reperfusion (R, slash) (A,C) and at different times after the equilibration period in normal metabolic conditions (backslash) $(\mathrm{B}, \mathrm{D})$. Values are mean \pm SEM of at least four experiments of the percentage variation of relative gene expression with respect to relative controls (empty bar). Vertical bars indicate SEM. ${ }^{\star} P<0.05$ by one sample $t$-test. The relative gene expression was determined by comparing $\Delta \Delta \mathrm{CT}$ values normalized to $\beta$-actin.

to mediate iNOS mRNA transcription under ischemic/ reperfusion conditions. ${ }^{41}$

In the guinea pig ileum, the concentrations of $\mathrm{NO}$ oxidation products, namely $\mathrm{NO}_{2}{ }^{-}$and $\mathrm{NO}_{3}{ }^{-}$, transiently increased at the onset of hypoxia/hypoglycaemia and after returning to an oxygenated glucosecontaining medium. This finding suggests that the first minutes after inducing in vitro ischemia and reperfusion are crucial moments for the modulation of NO synthesis in our model. NO is a reactive and unstable molecule and its half-life is estimated as a few seconds in biological specimens. ${ }^{42}$ Thus, to assess its synthesis in our preparations we have quantitatively determined the concentrations of its stable oxidation products, $\mathrm{NO}_{2}{ }^{-}$and $\mathrm{NO}_{3}{ }^{-}$resorting to a reproducible and sensitive spectrophotometric method assay based on the Griess reaction. ${ }^{43}$ In biological specimens, $\mathrm{NO}_{3}{ }^{-}$concentrations are in the micromolar range and are 10-100-fold higher than $\mathrm{NO}_{2}{ }^{-}$, since this latter $\mathrm{NO}$ oxidation product is almost completely oxidized to $\mathrm{NO}_{3}{ }^{-}$by oxyhaemoglobin or oxymyoglobin. ${ }^{44}$ In agreement with the literature, $\mathrm{NO}_{3}{ }^{-}$concentrations from ileal superfusate resulted in the micromolar range, although this value was just three fold higher than
$\mathrm{NO}_{2}{ }^{-}$concentrations. Higher $\mathrm{NO}_{2}{ }^{-}$levels may be explained considering that in the superfusing medium, consisting of an aqueous solution lacking of haemoproteins, $\mathrm{NO}_{2}{ }^{-}$are more stable and represent a conspicuous fraction of spontaneous $\mathrm{NO}$ oxidation products, as already suggested for the rabbit stomach and colon. ${ }^{45}$ Under normal metabolic conditions, the ability of $N^{\omega}$-propyl-L-arginine and $1400 \mathrm{~W}$, to decrease $\mathrm{NO}_{2}{ }^{-}$and $\mathrm{NO}_{3}{ }^{-}$levels is suggestive of a spontaneous NO release from the guinea pig ileum, which involves both nNOS and iNOS activation. Spontaneous NO synthesis has been demonstrated from the canine proximal colon, ${ }^{46}$ and may have a role in the inhibition of intestinal smooth muscle spontaneous excitability. ${ }^{47}$ Sensitivity to $1400 \mathrm{~W}$ strengthens the hypothesis of the presence of a constitutively active functional iNOS in the guinea pig ileum, as already suggested for the human colon and mouse ileum. ${ }^{21,48}$ Our immunohistochemical data suggest that, in our preparations, myenteric neurons may represent the major cellular population releasing $\mathrm{NO}$, via iNOS activation. Although we could not find evidence of either nNOS-IR or iNOS-IR in enteric glial cells by immunhistochemistry, we cannot entirely exclude the 

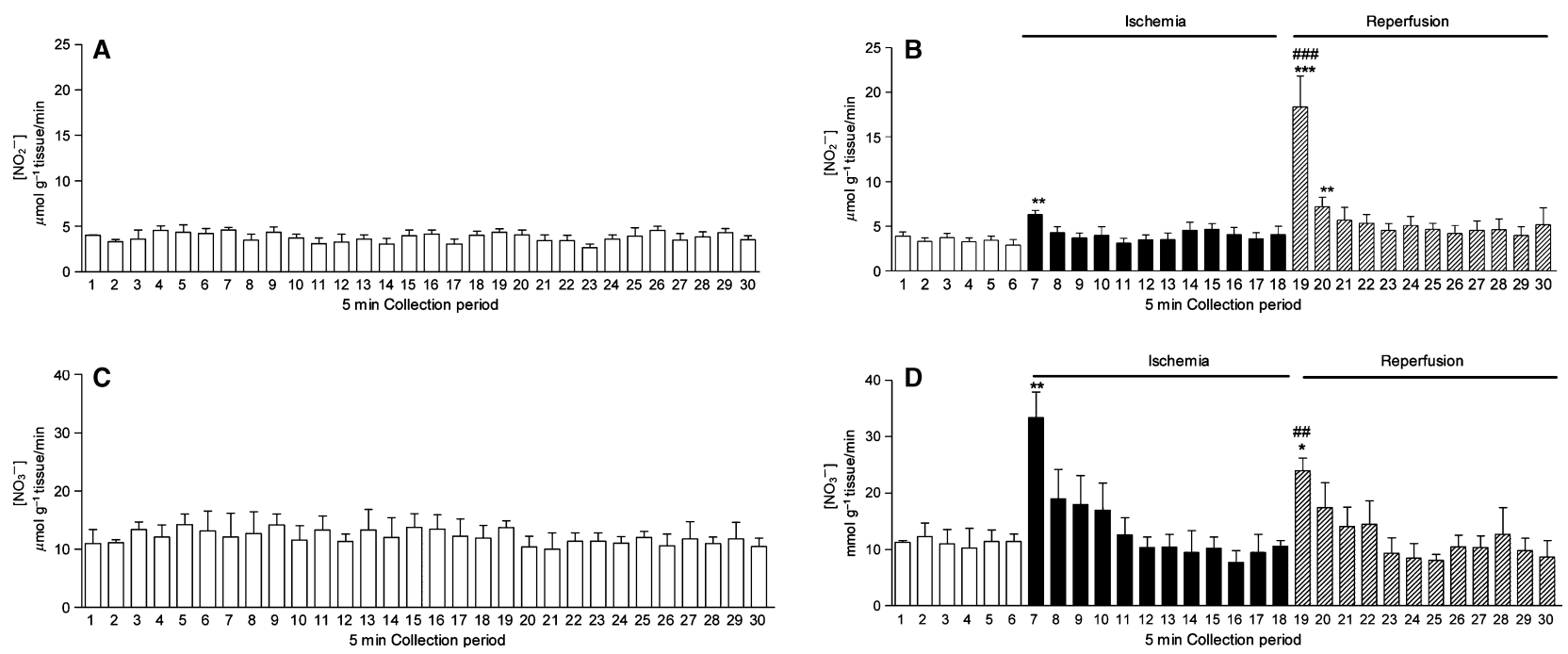

Figure $7 \mathrm{NO}_{2}{ }^{-}$and $\mathrm{NO}_{3}{ }^{-}$concentrations in the superfusate from isolated segments of the guinea pig ileum in normal (A,C), in in vitro ischemic conditions and during reperfusion after in vitro ischemia $(\mathrm{B}, \mathrm{D})$. Horizontal bars indicate the period of treatment. Each column is the mean of at least 4-7 experiments. Vertical bars indicate SEM, ${ }^{\star} P<0.05,{ }^{\star}{ }^{\star} P<0.01,{ }^{\star}{ }^{\star} P<0.001$ (vs controls) and ${ }^{\# \# P} P<0.01$, ${ }^{\# \# \#} P<0.01$ vs last six collections in ischemic conditions by one way ANOva followed by Tuckey's post hoc test.

participation of this cell population. Indeed, in astrocytes, which share many common morphological and functional features with enteric glial cells, iNOS represents a major source for NO under physiological conditions. ${ }^{40,49}$

After inducing both in vitro ischemia and reperfusion NO ileal levels rapidly and transiently increased via a NOS dependent pathway, involving both nNOS and iNOS, as suggested by the ability of $N^{\omega}$-propyl-Larginine and $1400 \mathrm{~W}$ to reduce the peak concentrations of both $\mathrm{NO}_{2}{ }^{-}$and $\mathrm{NO}_{3}{ }^{-}$. The higher sensitivity of $\mathrm{NO}_{3}{ }^{-}$levels to $1400 \mathrm{~W}$, with respect to $N^{\omega}$-propyl-Larginine, may be indicative of a major role played by iNOS in myenteric neurons during pathological conditions, as expected. However, during the first min after reperfusion, NOS may not represent the unique source for NO synthesis, as indicated by the partial ability of NOS inhibitors to decrease $\mathrm{NO}_{2}^{-}$levels, in these conditions. In this regard, we may hypothesize that a fraction of $\mathrm{NO}_{2}{ }^{-}$may originate from $\mathrm{NO}$ bound to scavengers, such as deoxygenated haemoglobin and myoglobin. ${ }^{50,51}$ Under hypoxic conditions, deoxyhemoglobin and deoxymyoglobin may mediate the nonenzymatic conversion of $\mathrm{NO}_{2}^{-}$to $\mathrm{NO}$, representing sources of NO. ${ }^{52}$ Additionally, we cannot exclude that, in the guinea pig ileum, NO may be stored in the form of molecular complexes, such as S-nitrosothiols and dinitrosyl iron complexes, from which NO can be subsequently released. ${ }^{53}$

In our model the relationship between NO production and changes of NOS expression is not consistent throughout the experiment, as already observed in the human colon from IBD patients. ${ }^{21}$ Indeed, the question whether an increase of NOS expression may lead to higher NO production is controversial. Recently in the rat myocardium elevation of NO levels during re-oxygenation after in vitro hypoxia was transitory and did not reflect the long lasting changes of both iNOS and eNOS expression and activity. ${ }^{54}$ In the guinea pig ileum, enhancement of NO synthesis during the first min after ischemia and reperfusion was paralleled by an increase of iNOS expression. However, nNOS protein levels remained unchanged suggesting that the possible enhancement of nNOS activity may depend upon post-translational events modulating the enzyme function. ${ }^{34}$ One of the possible mechanisms may be represented by a $\mathrm{Ca}^{++}$-dependent nNOS activation consequent to glutamate mediated overstimulation of myenteric NMDA receptors during the $\mathrm{I} / \mathrm{R}$ insult. $^{27}$ Reduction of NO levels during maintained in vitro ischemic conditions, in spite of the increased iNOS expression and the unchanged nNOS expression, may depend upon hypoxia-mediated inhibition of NOS activity. ${ }^{41,55}$ Furthermore, NO binding to scavenger molecules in the ileal tissue during both in vitro ischemia and reperfusion, may reduce the concentration of NO oxidized species in the superfusate. ${ }^{52}$ During reoxygenation of the ischemic tissue, NO may be captured by molecular components of the tissue and converted into reactive nitrogen species which contribute to protein nitrosative modifications, cellular apoptosis and necrosis. ${ }^{22,56}$

From a functional viewpoint, the boost of NO synthesis after an acute I/R damage may be the basis 

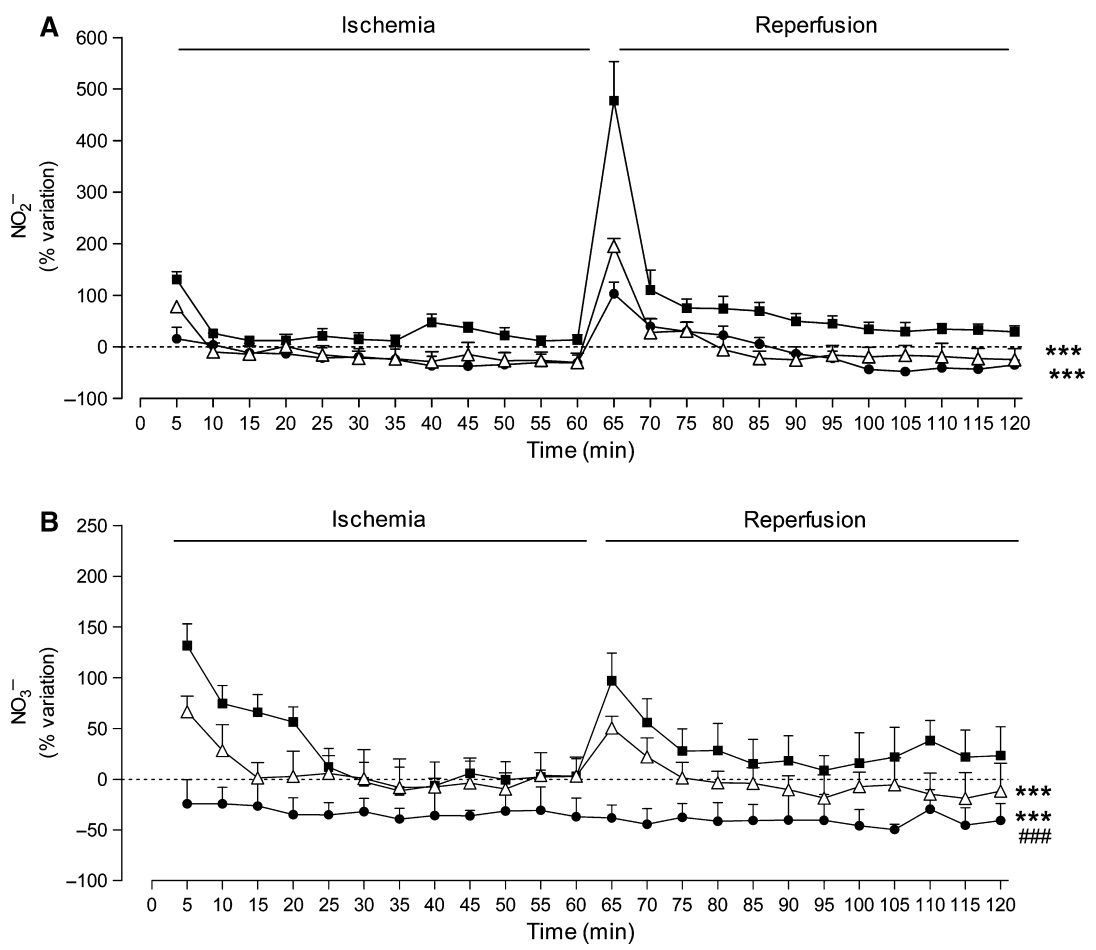

Figure 8 Effect of $N^{\omega}$-propyl-L-arginine $\left(1 \mu \mathrm{mol} \mathrm{L}{ }^{-1}\right)$ and $1400 \mathrm{~W}\left(10 \mu \mathrm{mol} \mathrm{L}^{-1}\right)$ on $\mathrm{NO}_{2}{ }^{-}(\mathrm{A})$ and $\mathrm{NO}_{3}{ }^{-}(\mathrm{B})$ production from the guinea pig ileum evoked by in vitro ischemia and reperfusion. Horizontal bars indicate the period of treatment. In vitro ischemia/reperfusion only $(\square) N^{\omega}$-propyl-L-arginine $(\triangle)$ and1400 W (•). Data are expressed as percentage variation with respect to values of spontaneous overflow obtained for each treatment in normal metabolic conditions. Each point represents the mean of 4-7 experiments. Vertical bars indicate SEM; ${ }^{{ }^{* *}} P<0.001$, by two way ANOvA VS in vitro ischemia/reperfusion only. ${ }^{\# \#} P<0.001$ vs $N^{\omega}$-propyl-L-arginine-treated preparations.

of the reduced muscular contractility described soon after an hypoxic injury to the intestine. ${ }^{10}$ Enhancement of NO synthesis may also retain an emergency function, exerting a vasodilator effect in order to regulate the blood flow through the hypoxic tissues. ${ }^{55}$ In addition, immediate iNOS expression changes, which are not reversed by reperfusion, and potential delayed alterations of nNOS protein may contribute to NO-mediated myenteric neuron damage underlying post-ischemic impairment of intestinal transit. $6,23,25$

In conclusion the present study has provided evidence that in the guinea pig ileum during in vitro I/R, both iNOS and nNOS are involved in acute overproduction of NO. Changes of iNOS protein, and possibly of nNOS protein, may participate to the delay of the intestinal transit and foster long lasting effects on enteric neuronal circuitries in these conditions. A more clear-cut differentiation of the function of different NOS isoforms in clinical conditions, such as during an ischemic gastrointestinal injury, may provide useful information about the pathophysiological basis of the disease and eventually lead to the devel- opment of pharmacological strategies targeting specific NOS.

\section{ACKNOWLEDGMENTS}

The authors wish to thank Dr Tiziana Lorenzi, Dr Paola Moretto and Mr Antonio Pelizzoli for the skilful assistance in performing some experiments. Mrs Luisa Guidali is kindly acknowledged for the excellent assistance in the acquisition of confocal images.

\section{FUNDING}

This study has been performed with grants from the Italian Ministry of University and Research and by the Universities of Insubria and of Pavia.

\section{DISCLOSURE}

The authors state no potential conflicts of interest.

\section{AUTHOR CONTRIBUTION}

GC analysed data, wrote the paper; GC EC, SM, RO EM, BB and DV designed the research study and performed the research; GF, SL and FC contributed to design the research and to discuss data. 


\section{REFERENCES}

1 Haglund $U$, Bergqvist D. Intestinal ischemia - the basics Langenbeck's. Arch Surg 1999; 384: 233-8.

2 Massberg S, Messmer K. The nature of ischemia/reperfusion injury. Transplant Proc 1998; 30: 4217-23.

3 Thornton M, Solomon MJ. Crohn's disease: in defense of a microvascular aetiology. Int I Colorectal Dis 2002; 17: 287-97.

4 Nowicki PT. Ischemia and necrotizing enterocolitis: where, when, and how. Semin Pediatr Surg 2005; 14: $152-8$.

5 Hierholzer C, Kalff JC, Audolfsson G, Billiar TR, Tweardy DJ, Bauer AJ. Molecular and functional contractile sequelae of rat intestinal ischemia/ reperfusion injury. Transplantation 1999; 68: 1244-54.

6 Lindeström LM, Ekblad E. Structural and neuronal changes in rat ileum after ischemia with reperfusion. Dig Dis Sci 2004; 49: 1212-22.

7 Pontell L, Sharma P, Rivera LR et al. Damaging effects of ischemia/reperfusion on intestinal muscle. Cell Tissue Res 2011; 343: 411-9.

8 Walus KM, Jacobson ED. Relation between small intestinal motility and circulation. Am J Physiol 1981; 241: G1-15.

9 Udassin R, Eimerl D, Schiffman J, Haskel Y. Postischemic intestinal motility in rat is inversely correlated to length of ischemia: an in vivo animal model. Dig Dis Sci 1995; 40: 1035-8.

10 Bielefeldt $\mathrm{K}$, Conklin JL. Intestinal motility during hypoxia and reoxygenation in vitro. Dig Dis Sci 1997; 42: 878-84.

11 Silva MACP, de Meirelles LR, Bustorff-Silva JM. Changes in intestinal motility and in the myenteric plexus in a rat model of intestinal ischemiareperfusion. I Ped Surg 2007; 42: 1062-5.

12 Furness JB. Types of neurons in the enteric nervous system. I Auton Nerv Syst 2000; 81: 87-96.

13 Holzer P, Lippe IT, Tabrizi AL, Lènárd L Jr, Barthó L. Dual excitatory and inhibitory effect of nitric oxide on peristalsis in the guinea pig intestine. J Pharmacol Exp Ther 1997; 280: 154-61.

14 Vannucchi MG, Corsani L, Bani D, Faussone-Pellegrini MS. Myenteric neurons and interstitial cells of Cajal of mouse colon express several nitric oxide synthase isoforms. Neurosci Lett 2002; 326: 191-5.

$15 \mathrm{Qu} \mathrm{ZD,} \mathrm{Thacker} \mathrm{M,} \mathrm{Castelucci} \mathrm{P,}$ Bagyánszki $M$, Epstein $M L$, Furness JB. Immunohistochemical analysis of neuron types in the mouse small intestine. Cell Tissue Res 2008; 334: 147-61.

16 Bernard CE, Gibbons SI, GomezPinilla PJ et al. Effect of age on the enteric nervous system of the human colon. Neurogastroenterol Motil 2009; 21: 746-e46.

17 Talapka P, Bódi N, Battonyai I, Fekete E, Bagyánszki M. Subcellular distribution of nitric oxide synthase isoforms in the rat duodenum. World I Gastroenterol 2011; 17: 1026-9.

18 Toda N, Herman AG. Gastrointestinal function regulation by nitrergic efferent nerves. Pharmacol Rev 2005; 57: 315-38.

19 Valentine JF, Tannahill CL, Stevenot SA, Sallustio JE, Nick HS, Eaker EY. Colitis and interleukin $1 \beta$ up-regulate inducible nitric oxide synthase and superoxide dismutase in rat myenteric neurons. Gastroenterology 1996 111: 56-64.

20 Miampamba M, Sharkey KA. Temporal distribution of neuronal and inducible nitric oxide synthase and nitrotyrosine during colitis in rats. Neurogastroenterol Motil 1999; 11: 193-206.

21 LePard KJ. Choline acetyltransferase and inducible nitric oxide synthase are increased in myenteric plexus of diabetic guinea pig. Auton Neurosci 2005; 118: 12-24.

22 Rivera LR, Thacker M, Pontell L, Cho HJ, Furness JB. Deleterious effects of intestinal ischemia/reperfusion injury in the mouse enteric nervous system are associated with protein nitrosylation. Cell Tissue Res 2011; 344: 111-23.

23 Hassoun HT, Weisbrodt NW, Mercer DW, Kozar RA, Moody FG, Moore FA. Inducible nitric oxide synthase mediates gut ischemia/reperfusioninduced ileus only after severe insults. J Surg Res 2001; 97: 150-4.

24 Ballabeni V, Barocelli E, Bertoni S, Impicciatore M. Alterations of intestinal motor responsiveness in a model of mild mesenteric ischemia/reperfusion in rats. Life Sci 2002; 71: 2025-35.

25 Calcina F, Barocelli E, Bertoni S et al. Effect of N-methyl-D-aspartate receptor blockade on neuronal plasticity and gastrointestinal transit delay induced by ischemia/reperfusion in rats. Neuroscience 2005; 134: 39-49.

26 Rivera LR, Thacker M, Castelucci P, Bron R, Furness JB. The reactions of specific neuron types to intestinal ischemia in the guinea pig enteric nervous system. Acta Neuropathol 2009; 118: 261-70.

27 Giaroni C, Zanetti E, Giuliani D et al. Protein kinase $\mathrm{C}$ modulates NMDA receptors in the myenteric plexus of the guinea pig ileum during in vitro ischemia and reperfusion. Neurogastroenterol Motil 2011; 23: e91-103.

28 Giaroni C, Zanetti E, Pascale A et al. Involvement of $\mathrm{Ca}^{2+}$-dependent PKCs in the adaptive changes of mu-opioid pathways to sympathetic denervation in the guinea pig colon. Biochem Pharmacol 2009; 78: 1233 41.

29 Laemmli UK. Cleavage of structural proteins during the assembly of the head of bacteriophage T4. Nature 1970; 227: 680-5.

30 Vigetti D, Clerici M, Deleonibus S et al. Hyaluronan synthesis is inhibited by adenosine monophosphateactivated protein kinase through the regulation of HAS2 activity in human aortic smooth muscle cells. I Biol Chem 2011; 286: 7917-24.

31 Sun J, Zhang X, Broderick M., Fein H. Measurement of nitric oxide production in biological systems by using Griess reaction assay. Sensors 2003; 3: 276-84.

32 Tomobuchi $M$, Oshitani N, Matsumoto T, Kitano A, Seki S, Arakawa $\mathrm{T}$. In situ generation of nitric oxide by myenteric neurons but not by mononuclear cells of the human colon. Clin Exp Pharmacol Physiol 2001; 28: 13-8.

33 Prabhakar NR, Pieramici SF, Premkumar DR, Kumar GK, Kalaria RN. Activation of nitric oxide synthase gene expression by hypoxia in central and peripheral neurons. Mol Brain Res 1996; 43: 341-6.

34 Zhou L, Zhu DY. Neuronal nitric oxide synthase: structure, subcellular localization, regulation, and clinical implications. Nitric Oxide 2009; 20: 223-30.

35 Ward ME, Toporsian M, Scott JA et al. Hypoxia induces a functionally significant and translationally efficient neuronal NO synthase mRNA variant. I Clin Invest 2005; 115: 3128-39. 
36 Miller MJS, Thompson JH, Zhang XJ et al. Role of inducible nitric oxide synthase expression and peroxynitrite formation in guinea pig ileitis. Gastroenterology 1995; 109: 1475-83.

37 Green CL, Ho W, Sharkey KA, McKay DM. Dextran sodium sulfate-induced colitis reveals nicotinic modulation of ion transport via iNOS-derived NO. Am I Physiol Gastrointest Liver Physiol 2004; 287: G706-14.

38 Brown GC. Nitric oxide and neuronal death. Nitric Oxide 2010; 23: 153-65.

39 Moro MA, De Alba J, Leza JC et al. Neuronal expression of inducible nitric oxide synthase after oxygen and glucose deprivation in rat forebrain slices. Eur I Neurosci 1998; 10: 445-6.

40 Giaroni C, De Ponti F, Cosentino M, Lecchini S, Frigo GM. Plasticity in the enteric nervous system. Gastroenterology 1999; 117: 1438-58.

41 Robinson MA, Baumgardner JE, Otto CM. Oxygen-dependent regulation of nitric oxide production by inducible nitric oxide synthase. Free Radic Biol Med 2011; 51: 1952-65.

42 Moncada S, Palmer RMJ, Higgs EA. The discovery of nitric oxide as the endogenous nitrovasodilator. Hypertension 1988; 12: 365-72.

43 Tsikas D, Fuchs I, Gutzki FM, Frölich JC. Measurement of nitrite and nitrate in plasma, serum and urine of humans by high-performance liquid chromatography, the Griess assay, chemiluminescence and gas chromatography-mass spectrometry: interferences by biogenic amines and $\mathrm{N}(\mathrm{G})$-nitro-L-arginine analogs. I Chromatogr B Biomed Sci Appl 1998; 715: 441-4.

44 Ignarro LJ, Fukuto JM, Griscavage JM, Rogers NE, Byrns RE. Oxidation of nitric oxide in aqueous solution to nitrite but not nitrate: comparison with enzymatically formed nitric oxide from L-arginine. Proc Natl Acad Sci USA 1993; 90: 8103-7.

45 Iversen $\mathrm{HH}$, Celsing F, Leone AM, Gustafsson LE, Wiklund NP. Nerveinduced release of nitric oxide in the rabbit gastrointestinal tract as measured by $s$ microdialysis. Br I Pharmacol 1997; 120: 702-6.

46 Shuttleworth CWR, Weinert JS, Sanders KM, Buxton ILO. Detection of nitric oxide release from canine enteric neurons. I Auton Nerv Syst 1995; 56: 61-8.

47 Ward SM, Dalziel HH, Bradley ME et al. Involvement of cyclic GMP in non-adrenergic, non-cholinergic inhibitory neurotransmission in dog proximal colon. Br I Pharmacol 1992; 107: 1075-82.

48 Bagyánski $M$, Torfs $\mathrm{P}$, Krecsmarik $\mathrm{M}$ et al. Chronic alcohol consumption induces an overproduction of NO by nNOS- and iNOS-expressing myenteric neurons in the murine small intestine. Neurogastroenterol Motil 2011; 23: e237-48.
49 Amitai Y. Physiologic role for "inducible" nitric oxide synthase: a new form of astrocytic-neuronal interface. Glia 2010; 58: 1775-81.

50 Crawford JH, Isbell TS, Huang Z et al. Hypoxia, red blood cells, and nitrite regulate NO-dependent hypoxic vasodilation. Blood 2006; 107: 566-74.

51 Rassaf $\mathrm{T}$, Flögel U, Drexhage C, Hendgen-Cotta U, Kelm M, Schrader J. Nitrite reductase function of deoxymyoglobin: oxygen sensor and regulator of cardiac energetics and function. Circ Res 2007; 100: 1749-54.

52 Lundberg JO, Weitzberg E, Gladwin MT. The nitrate-nitrite-nitric oxide pathway in physiology and therapeutics. Nat Rev Drug Discov 2008; 7: 156-67.

53 Hughes MN. Relationships between nitric oxide, nitroxyl ion, nitrosonium cation and peroxynitrite. Biochim Biophys Acta 1999; 1411: 263-72.

54 Rus A, Del Moral ML, Molina F, Peinado MA. Upregulation of cardiac $\mathrm{NO} / \mathrm{NOS}$ system during short-term hypoxia and the subsequent reoxygenation period. Eur I Histochem 2011; 55: 90-96.

55 Nankervis CA, Miller CE. Developmental differences in response of mesenteric artery to acute hypoxia in vitro. Am I Physiol Gastrointest Liver Physiol 1998; 37: G694-9.

56 Esplugues JV. NO as a signalling molecule in the nervous system. Br J Pharmacol 2002; 135: 1079-95. 